\title{
Krystyna Chałas, Dydaktyka akademicka w uniwersytecie katolickim. T. 1. Dydaktyka zaangażowana - z doświadczeń Katedry Dydaktyki i Edukacji Szkolnej KUL, Wydawnictwo KUL, Lublin 2019, ss. 213
}

Na rynku księgarskim pojawiają się liczne publikacje z zakresu edukacji o zachęcających tytułach, lecz nie wszystkie spełniają oczekiwania tych osób czy grup ludzkich, do których są adresowane. I oto do rąk czytelników trafia książka stanowiąca efekt 20-letnich doświadczeń w obszarze teoretycznych przesłanek i praktycznych rozwiązań sposobów kształcenia studentów pedagogiki ze specjalnością nauczycielską; niekonwencjonalnych nierzadko form aktywności Katedry Dydaktyki i Edukacji Szkolnej, funkcjonującej w strukturach organizacyjnych Katolickiego Uniwersytetu Lubelskiego Jana Pawła II pod prężnym kierownictwem autorki recenzowanego opracowania prof. zw. dr hab. Krystyny Chałas.

Autorka podjęła namysł nad specyfiką dydaktyki akademickiej w służbie kształcenia przyszłych nauczycieli. W tym celu poddała analizie: 1) teorie i przesłanki teoretyczne mogące stanowić podstawę budowania owej specyfiki; 2) przedstawiła szereg konstruktywnych rozwiązań praktycznych usytuowanych w przyjętej podstawie teoretycznej, nade wszystko skutecznie przygotowujących przyszłych nauczycieli do zadań i wyzwań, jakie stawia ustawicznie reformowana szkoła, społeczeństwo, państwo i kościół. Wychodząc naprzeciw konieczności ciągłego podwyższania jakości kształcenia, podjęcie tej problematyki należy uznać za niezwykle cenne i ze wszech miar uzasadnione.

\footnotetext{
1 Anna Karpińska, Wydział Pedagogiki i Psychologii, Uniwersytet w Białymstoku, Polska, e-mail: a.karpinska@uwb.edu.pl.
} 
Pragnę podkreślić, iż tematyka recenzowanej monografii mieści się w nurcie najnowszych tendencji odnotowywanych w dydaktyce jako nauce i wychodzi naprzeciw oczekiwaniom wobec edukacji akademickiej kształcącej nauczycieli XXI wieku.

Treść książki jest logicznie i merytorycznie uporządkowanym materiałem wokół konsekwentnie wytyczonego i sformułowanego we Wstępie celu, podporządkowanego idei zawartej w tytule dzieła.

Już wgląd w strukturę książki, która jest przejrzysta, klarowna i konsekwentnie utrzymana, zachęca do jej uważnej lektury, gdyż obiecuje uporządkowanie myśli, jasność wywodu i łatwość wybiórczego odnajdowania w tekście interesujących wątków. Opracowanie składa się z czterech rozdziałów, wewnętrznie zgrabnie, wręcz modelowo ustrukturyzowanych, z wyraźnie wyodrębnionymi podtytułami. Każdy z rozdziałów zawiera podsumowanie/konkluzję, co niewątpliwie należy uznać za zaletę, ułatwia bowiem scalenie pewnych myśli i ustalenie stanu informacji wyjściowych dla efektywniejszego konstruowania wiedzy. Całość opatrzona została Wstępem, zdradzającym intencję powstania książki oraz informującym o jej konstrukcji; rozbudowanym Aneksem oraz wyselekcjonowaną Bibliografiq, dobraną w sposób uzasadniony wiodącą problematyką dzieła. Należy zaznaczyć, iż struktura książki jest wewnętrznie spójna, a dobór i układ treści został podporządkowany logice prezentowanego dyskursu pedagogicznego.

Tytuł książki w pełni odpowiada jej merytorycznej zawartości, co dotyczy także tytułów każdej z wymienionych części.

Lektura tekstu sprawiła mi dużą intelektualną przyjemność, nie tylko jako nauczycielowi akademickiemu, który dba o jakość dydaktyki i doskonalenie procesu kształcenia, ale także jako kierownikowi współpracującego Zakładu Dydaktyki Ogólnej. Dostarczyła bowiem wzorców, jak skutecznie organizować pracę dydaktyczną, naukową, a także aktywność formalną i nieformalną pracowników Zakładu w ramach tzw. dobrych praktyk.

Część pierwsza opracowania ukazuje ogólną specyfikę dydaktyki akademickiej w kontekście misji katolickiego uniwersytetu, w tym Katolickiego Uniwersytetu Jana Pawła II oraz Instytutu Pedagogiki KUL. Uchwycenie tej specyfiki dało podstawę do nakreślenia nowego paradygmatu dydaktyki akademickiej w katolickim uniwersytecie, który określono mianem paradygmatu integralnego i odniesiono do zaangażowania i twórczości pedagogicznej studenta - przyszłego nauczyciela.

W rozdziale tym znajdujemy definicyjne ujęcie „dydaktyki” od czasów J.A. Komeńskiego, J.F. Herbarta, J. Deweya, przez poglądy pedagogów okresu międzywojennego - B. Nawroczyńskiego, K. Sośnickiego i okresu bliższego naszym czasom - W. Okonia, Cz. Kupisiewicza, W. Zaczyńskiego, F. Bereź- 
nickiego; po ujęcia współczesne - St. Palki (2003), J. Półturzyckiego (2014), a wśród nich nowe podejścia do dydaktyki, w tym dydaktyki akademickiej jako nauki wieloparadygmatycznej - D. Klus-Stańskiej (2018), B.D. Gołębniak (2006), A. Sajdak (2013).

Z uwagi na rangę konstytutywnego pojęcia recenzowanego opracowania autorka szczególną refleksją otacza „dydaktykę akademicką” będącą dydaktyką szczegółową. Odnotowuje - co warte podkreślenia a tym samym „chroni od zapomnienia” znaczący wkład określonych środowisk naukowych w rozwój polskiej myśli naukowej w zakresie szkoły wyższej, m.in. Ogólnopolskich Seminariów Pedagogiki Szkoły Wyższej pod naukowym kierownictwem profesora Kazimierza Jaskota (USz); cyklicznych Augustowskich Spotkań Naukowych „Edukacja w dialogu i perspektywie” pod kierunkiem naukowym profesor Anny Karpińskiej (UwB), podczas których stałym profilem czyni się zagadnienia związane z dydaktyką szkoły wyższej.

Nie pomija też niekwestionowanych zasług profesora Kazimierza Denka autora m.in. swoistego tryptyku poświęconego uniwersytetowi (Denek, 2011) i jego cyklicznych Tatrzańskich Sympozjów Naukowych „Edukacja Jutra” dla dorobku dydaktyki akademickiej.

Część druga recenzowanej książki zawiera dobrze skonstruowaną mapę teoretycznych przesłanek dydaktyki zaangażowanej, akcentując teoretyczne podstawy pedagogiki personalistycznej, teoretyczne podstawy integralnego rozwoju człowieka w odniesieniu do ucznia i studenta, aplikację przez L. Witkowskiego (2010) na grunt pedagogiki teorii tożsamości J. Habermasa oraz teorię społecznego uczenia się A. Bandury (2007). Problematyka ta, w postaci charakterystyki czterech teorii będących podstawą praktycznych działań w kształceniu studentów z uzasadnieniem ich zastosowania, znajduje bardzo interesującą odpowiedź w dalszej części rozdziału jako przedstawienie centralnego punktu dydaktyki zaangażowanej, który stanowi nadrzędny cel szkoły oraz jej kultura.

Na uwagę zasługuje charakterystyka roli i funkcji nauczyciela akademickiego katolickiego uniwersytetu w perspektywie dydaktyki zaangażowanej, której „,rdzeniem” jest zagadnienie integralnego rozwoju osoby studenta jako nadrzędnego celu szkoły wyższej.

Pragnę podkreślić kompetentnie przeprowadzone studia literaturowe, prezentowanie definicji czy też przesłanek w optyce najważniejszych podejść teoretycznych.

W rozdziale trzecim autorka na podstawie własnych doświadczeń dydaktycznych podejmuje próbę odpowiedzi na pytanie: „W jaki sposób kształcić kompetencje nauczycielskie w perspektywie dydaktyki zaangażowanej, wyzwalającej twórczy potencjał studentów, by w przyszłości byli autorytetami nauczycielskimi, 
by przez swoją działalność twórczą optymalizowali warunki integralnego rozwoju ucznia i kultury szkoły, poprzez którą te warunki są spełnione?” (s. 138).

Opis wybranych elementów kształcenia przyszłych nauczycieli w kontekście kształtowania ich kompetencji pedagogicznych, poprzedzony ukazaniem przestrzeni treści programowych kształcenia akademickiego KUL, ze szczególną ich prezentacją w zakresie nauczanych przez autorkę przedmiotów (dydaktyka ogólna, aksjologia edukacji szkolnej, pedagogika szkoły, światowe, europejskie i polskie systemy wychowawczo-dydaktyczne w edukacji elementarnej), stanowi interesujące dopełnienie analizy stanowisk wybranych autorów w obszarze kompetencji nauczycielskich obecnych w literaturze pedeutologicznej.

Czwarty rozdział recenzowanej książki to - w moim odczuciu - kwintesencja nadzwyczaj twórczej, kreatywnej i oryginalnej pracy naukowej i popularyzatorskiej prof. zw. dr hab. Krystyny Chałas, pracowników Jej Katedry oraz studentów KUL, a także całej rzeszy nauczycieli skupionych wokół szkoły naukowej Pani Profesor. Zamieszczona w tej części książki charakterystyka form edukacji akademickiej organizowanych przez Katedrę, wpisujących się w strategię edukacji podmiotowej, mających najczęściej charakter pozaformalny i opierających się na społecznym działaniu i udziale w formach pracy dydaktyczno-wychowawczej i formacyjnej - to wyraz ogromnego zaangażowania w proces kształcenia przyszłych nauczycieli, zdecydowanie wykraczający poza realizację pensum dydaktycznego; to świadectwo ich pasji - dynamizującej i motywującej - także innych uczestników procesu kształcenia; determinacji, entuzjazmu, identyfikacji z zawodem, służby społecznej i misji. Bez osoby lidera - profesor Krystyny Chałas, jej tytanicznej pracowitości, systematyczności i charyzmy oraz osobliwego daru zjednywania sobie ludzi - niemożliwa byłaby tak wielostronna, wieloaspektowa i wielopłaszczyznowa działalność Katedry Dydaktyki i Edukacji Szkolnej. To „dydaktyczna wartość dodana”, która zasługuje na uznanie i szacunek. Stąd dobrze się stało, że owe działania, stanowiące o tożsamości Katedry, ich szczegółowe cele, struktura oraz rezultaty, zostały przedstawione w książce i w ten sposób „ocalone od zapomnienia”. Warto przywołać w tym miejscu przynajmniej niektóre formy pracy, które stworzyły szansę wzbogacania doświadczeń poznawczych i praktycznych studentów: ogólnopolskie konkursy na świadectwo wartościom i biografie wzorów osobowych godnych naśladowania; seminarium wymiany doświadczeń pedagogicznych dla nauczycieli edukacji wczesnoszkolnej i przedszkolnej oraz studentów pedagogiki; sesje „Uczę się Ciebie, nauczycielu”; klub promocji talentów; udział w wydarzeniach roku liturgicznego.

Integralną częścią książki jest rozbudowany Aneks, który ma wartość dokumentacyjną i źródłową. Zawiera bowiem notki biograficzne pracowników Katedry, 
wybrane fakty historyczne funkcjonowania Katedry, rejestr wybranych publikacji pracowników, ich obszary badawcze oraz formy służby na rzecz rozwoju polskiej szkoły i oświaty.

Najnowsza monografia Krystyny Chałas wyróżnia się znacznym potencjałem naukowo-poznawczym, wzbogacającym pedagogikę szkoły wyższej w obszarze dydaktyki akademickiej. Łączy zalety interesującej poznawczo i poprawnej metodologicznie publikacji naukowej, jak również nośnika o charakterze aplikacyjnym.

Książka stanowi wartościowe teoretycznie, ubogacone w praktyczne doświadczenia studium monograficzne, które ukazuje bogate spektrum działań pracowników Katedry Dydaktyki i Edukacji Szkolnej KUL, służących idei kształcenia kandydatów na nauczycieli w duchu dydaktyki zaangażowanej.

Książka, której problematyka dotyczy szkoły wyższej, zwłaszcza dydaktyki akademickiej, jest niezwykle potrzebna i pożądana z racji teoretycznych, poznawczych i utylitarnych. Monografia mieści się w tych kontekstach, znakomicie ukazuje zarówno od strony teoretycznej, jak i praktycznych rozwiązań Autorki opracowania w ramach nauczanych przedmiotów oraz działań formalnych i pozaformalnych tworzonych wespół z pracownikami Katedry - to, o co konsekwentnie upominamy się, my, dydaktycy ogólni - poszerzanie i wzbogacanie pola poznawczego współczesnej dydaktyki (Karpińska, 2008) jako jednej z podstawowych, kanonicznych nauk pedagogicznych.

Ponadto, co warto podkreślić, prezentowane opracowanie należy do tych, które mieszczą się w jakże ważnym i potrzebnym nurcie aktywności naukowej i pisarskiej, który można by określić mianem „ocalić od zapomnienia”.

\section{Bibliografia}

Bandura, A. (2007). Teoria społecznego uczenia się. Warszawa: Wydawnictwo Naukowe PWN.

Denek, K. (2011). Uniwersytet w perspektywie społeczeństwa wiedzy. T. I-III. Poznań: Wydawnictwo Wyższej Szkoły Pedagogiki i Administracji im. Mieszka I w Poznaniu.

Gołębniak, B.D. (red.). (2006). Uczenie metodq projektów. Warszawa: Wydawnictwa Szkolne i Pedagogiczne.

Karpińska, A. (red.). (2008). Pola poznawcze dydaktyki w dialogu i perspektywie. Białystok: Wydawnictwo Uniwersyteckie Trans Humana.

Klus-Stańska, D. (2018). Paradygmaty dydaktyki. Myśleć teoriq o praktyce. Warszawa: Wydawnictwo Naukowe PWN.

Palka, S. (2003). Pedagogika w stanie tworzenia. Kontynuacje. Kraków: Wydawnictwo Uniwersytetu Jagiellońskiego. 
Półturzycki, J. (2014). Niepokój o dydaktykę. Warszawa-Radom: Wydawnictwo Instytutu Technologii Eksploatacji - Państwowy Instytut Badawczy.

Sajdak, A. (2013). Paradygmaty kształcenia studentów i wspierania rozwoju nauczycieli akademickich. Teoretyczne podstawy dydaktyki akademickiej. Kraków: Wydawnictwo „Impuls”.

Witkowski, L. (2010). Tożsamość i zmiana. Epistemologia i rozwojowe profile w edukacji. Wrocław: Wydawnictwo Naukowe Dolnośląskiej Szkoły Wyższej Edukacji TWP. 